\title{
Receptor Tyrosine-Protein Kinase erbB-3
}

National Cancer Institute

\section{Source}

National Cancer Institute. Receptor Tyrosine-Protein Kinase erbB-3. NCI Thesaurus.

Code C18490.

Receptor tyrosine-protein kinase erbB3 (1342 aa, 148 kDa) is encoded by the human ERBB3 gene. This protein plays a role in protein amino acid phosphorylation. 